\title{
Radiosynthesis of a carbon-11-labeled AMPAR allosteric modulator as a new PET radioligand candidate for imaging of Alzheimer's disease
}

\author{
Caihong Miao ${ }^{\mathrm{a}}$, Fugui Dong ${ }^{\mathrm{a}}$, Limeng Jia ${ }^{\mathrm{a}}$, Wei Li ${ }^{\mathrm{a}}$, Min Wang ${ }^{\mathrm{b}}$, Qi-Huang Zheng,*, \\ Zhidong $\mathrm{Xu}^{\mathrm{a}, \mathrm{c}, \mathrm{d} *}$
}

${ }^{a}$ Key Laboratory of Medicinal Chemistry and Molecular Diagnosis of Ministry of Education, College of Chemistry and Environmental Science, Hebei University, Baoding, Hebei 071002, China

${ }^{b}$ Department of Radiology and Imaging Sciences, Indiana University School of Medicine, 1345 West $16^{\text {th }}$ Street, Room 202, Indianapolis, IN 46202, USA

${ }^{c}$ College of Chemical \& Pharmaceutical Engineering, Key Laboratory of Molecular Chemistry for Medicine of Hebei Province, Hebei University of Science \& Technology, Shijiazhuang, Hebei 050018, China

dShijiazhuang Vince Pharmatech Co., Ltd., Shijiazhuang, Hebei 050030, China

*Corresponding authors. E-mail address: qzheng@iupui.edu (Q.-H. Zheng); zhidongxu@hbu.edu.cn (Z. Xu).

This is where the receipt/accepted dates will go; Received Month XX, 2019; Accepted Month XX, 2019 [BMCL RECEIPT]

\begin{abstract}
To develop PET tracers for imaging of Alzheimer's disease, a new carbon-11-labeled AMPAR allosteric modulator 4cyclopropyl-7-(3-[ $\left[{ }^{11} \mathrm{C}\right]$ methoxyphenoxy)-3,4-dihydro-2H-benzo[e][1,2,4]thiadiazine 1,1-dioxide $\left(\left[{ }^{11} \mathrm{C}\right] \mathbf{8}\right)$ has been synthesized. The reference standard 4-cyclopropyl-7-(3-methoxyphenoxy)-3,4-dihydro-2H-benzo[e][1,2,4]thiadiazine 1,1 -dioxide $(\mathbf{8})$ and its corresponding desmethylated precursor 4-cyclopropyl-7-(3-hydroxyphenoxy)-3,4-dihydro-2H-benzo[e][1,2,4]thiadiazine 1,1-dioxide (9) were synthesized from 4-methoxyabiline and chlorosulfonyl isocyanate in eight and nine steps with $3 \%$ and $1 \%$ overall chemical yield, respectively. The target tracer $\left[{ }^{11} \mathrm{C}\right] \mathbf{8}$ was prepared from the precursor 9 with $\left[{ }^{11} \mathrm{C}\right] \mathrm{CH}_{3} \mathrm{OTf}$ through $O-\left[{ }^{11} \mathrm{C}\right]$ methylation and isolated by HPLC combined with SPE in 10-15\% radiochemical yield, based on $\left[{ }^{11} \mathrm{C}_{C} \mathrm{CO}_{2}\right.$ and decay corrected to end of bombardment (EOB). The radiochemical purity was $>99 \%$, and the molar activity $\left(\mathrm{A}_{\mathrm{M}}\right)$ at EOB was $370-740 \mathrm{GBq} / \mu \mathrm{mol}$ with a total synthesis time of 35-40-minutes from EOB.
\end{abstract}

Keywords: $\alpha$-Amino-3-hydroxy-5-methyl-4-isoxazolepropionic acid receptor (AMPAR); Carbon-11-labeled AMPAR allosteric modulator; Radiosynthesis; Positron emission tomography (PET); Alzheimer's disease (AD).

Imaging has played a variety of important roles in the study of Alzheimer's disease (AD). ${ }^{1}$ Neuroimaging of $\mathrm{AD}$ becomes one of the particularly active as well as most challenging areas in neuroscience. ${ }^{2}$ Advanced biomedical imaging technique positron emission tomography (PET) is a promising modality for $\mathrm{AD}$, and significant advances have occurred in this field of molecular imaging. ${ }^{3}$ The development of PET imaging probes for in vivo detection of Alzheimer's brains is critical for early and accurate diagnosis and for the successful discovery of AD therapies. ${ }^{4}$ Previous PET AD imaging agent development is based on cholinergic hypothesis, amyloid hypothesis, and tau hypothesis. The representative PET tracers in clinical evaluations such as carbon-11-labeled AChEIs $\left[{ }^{11} \mathrm{C}\right] \mathrm{AMP}\left(\left[{ }^{11} \mathrm{C}\right] \mathrm{MP} 4 \mathrm{~A}\right)$, $\left[{ }^{11} \mathrm{C}\right] \mathrm{PMP}\left(\left[{ }^{11} \mathrm{C}\right] \mathrm{MP} 4 \mathrm{P}\right)$, and $\left[{ }^{11} \mathrm{C}\right]$ Donepezil $;{ }^{5-7} \quad \beta-$ amyloid plaques $(\mathrm{A} \beta)$ tracers $\left[{ }^{11} \mathrm{C}\right] \mathrm{PIB}$ and $\left[{ }^{18} \mathrm{~F}\right]$ Amyvid $\left(\left[{ }^{18} \mathrm{~F}\right] \mathrm{AV}-45\right) ;{ }^{8,9}$ and tau tracers $\left[{ }^{11} \mathrm{C}\right] \mathrm{PBB} 3$ and 
$\left.\left[{ }^{18} \mathrm{~F}\right] \mathrm{T} 807\left(\left[{ }^{18} \mathrm{~F}\right] \mathrm{AV}-1451\right)\right)^{10,11}$ are listed in Figure 1. The success and limitations of $A \beta$ imaging and tau imaging have spurred efforts worldwide to develop new selective PET tracers for different imaging targets. Our efforts toward the development of PET agents for AD diagnosis have been ongoing quite some time, and a series of enzyme- or receptor-based PET agents has been developed in this laboratory. For example, we have targeted the enzyme glycogen synthase kinase-3 (GSK-3) and developed carbon-11-labeled GSK-3 inhibitors ${ }^{12,13}$ as PET AD imaging agents (Figure 1).
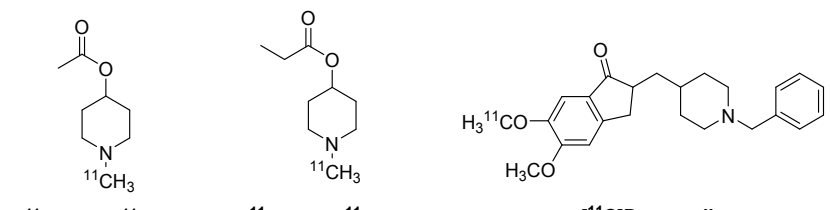

$\left[{ }^{11} \mathrm{C}\right] A M P\left(\left[{ }^{11} \mathrm{C}\right] M P 4 A\right) \quad\left[{ }^{11} \mathrm{C}\right] P M P\left(\left[{ }^{11} \mathrm{C}\right] M P 4 P\right)$

$\left[{ }^{11} \mathrm{C}\right]$ Donepezil
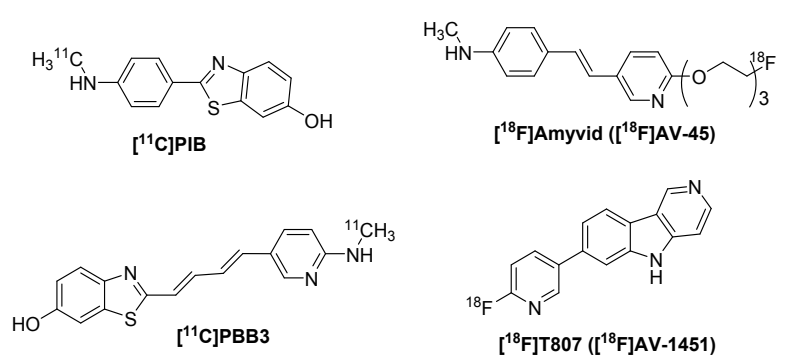

$\left[{ }^{18} \mathrm{~F}\right] \mathrm{T} 807\left(\left[{ }^{18} \mathrm{~F}\right] \mathrm{AV}-1451\right)$
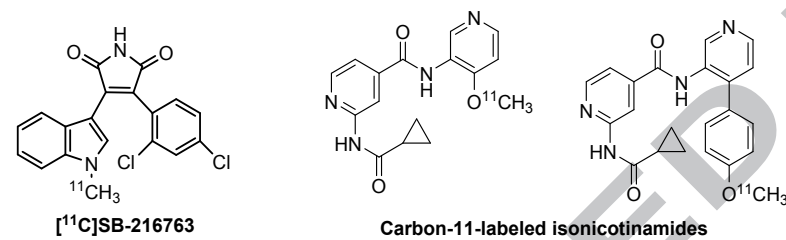

Figure 1. PET radiotracers for imaging of $\mathrm{AD}$.

In this continued effort, we revisit $\alpha$-amino-3-hydroxy5-methyl-4-isoxazolepropionic acid receptor (AMPAR), which is a novel and attractive molecular target for treatment and PET imaging of AD. ${ }^{14,15} \mathrm{We}$ and other groups have developed several AMPAR PET tracers, ${ }^{15-}$ ${ }^{21}$ and representative radioligands are shown in Figure 2. However, preclinical and clinical evaluation indicated these radioligands have significant drawbacks like not potent enough in vitro $\mathrm{IC}_{50}$ and/or $\mathrm{K}_{\mathrm{i}}$ values, low specific binding, high non-specific binding, poor brain entry, inconsistent brain uptake compared to known AMPAR distribution, and small dynamic range and metabolite in the brain. ${ }^{15-21}$ Thus an ideal AMPAR radioligand that can be used in the clinical setting to study AMPAR expression levels in AD remains to be discovered. Recently a novel series of 7-phenoxysubstituted 3,4-dihydro-2H-1,2,4-benzothiadiazine 1,1dioxides have been developed as positive allosteric modulators of AMPARs with nanomolar potency for potential treatment of $\mathrm{AD}$, and the lead compound, 4cyclopropyl-7-(3-methoxyphenoxy)-3,4-dihydro- $2 \mathrm{H}$ - benzo[e][1,2,4]thiadiazine 1,1-dioxide (8), exhibited high potency with $\mathrm{EC}_{50}=2.0 \mathrm{nM} .^{14}$ This compound has the combination of favorable in vitro activity to AMPAR, and $O$ - or $N$-methyl positions amenable to labeling with carbon-11, therefore, its carbon-11-labeled radioligand is expected to have high specific binding. Here, we report the design, synthesis and labeling of a carbon-11-labeled AMPAR allosteric modulator, 4cyclopropyl-7-(3-[ $\left.{ }^{11} \mathrm{C}\right]$ methoxyphenoxy)-3,4-dihydro-

$2 \mathrm{H}$-benzo $[e][1,2,4]$ thiadiazine 1,1 -dioxide $\quad\left(\left[{ }^{11} \mathrm{C}\right] \mathbf{8}\right)$ (Figure 2), as a new candidate PET radioligand for imaging of AD.
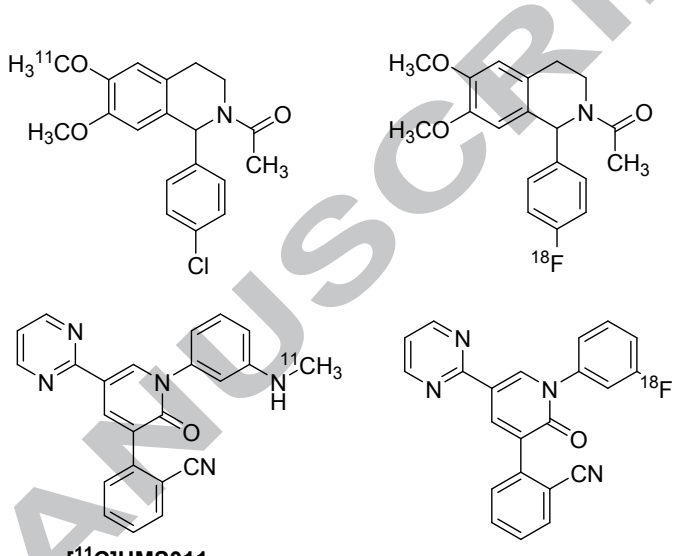

$\left[{ }^{11} \mathrm{C}\right] \mathrm{HMS011}$
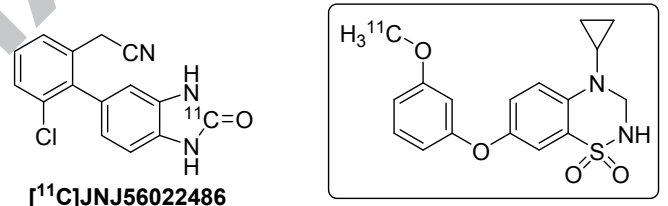

Figure 2. AMPAR PET radioligands.

Synthesis of the reference standard $\mathbf{8}$ and its desmethylated precursor 4-cyclopropyl-7-(3hydroxyphenoxy)-3,4-dihydro- $2 H$ -

benzo[ $e][1,2,4]$ thiadiazine 1,1-dioxide (9) is outlined in Scheme 1 according to the reported procedures. ${ }^{14,} 22-27$ The commercially available starting material 4methoxyaniline was reacted with sulfurisocyanatidic chloride following a modified procedure ${ }^{22}$ by using 1nitropropane as solvent to give 7-methoxy- $2 \mathrm{H}$ benzo[ $e][1,2,4]$ thiadiazin-3(4H)-one 1,1-dioxide (1), which resulted in a better yield $(82 \%)$ and safer operation. An easy and efficient preparation for hydrolysis of compound $\mathbf{1}$ in $50 \%$ aqueous $\mathrm{H}_{2} \mathrm{SO}_{4}$ under heating afforded 2-amino-5methoxybenzenesulfonamide (2) in 46\% yield. Compound $\mathbf{2}$ was reacted with 1-ethoxycyclopropyloxy trimethylsilane in methanol through a transacetalization reaction in the presence of glacial acetic acid $(\mathrm{AcOH})$ to generate 5-methoxy-2-((1methoxycyclopropyl)amino)benzenesulfonamide (3) in $61 \%$ yield. After the reduction of $\mathrm{NaBH}_{4}$ with boron trifluoride diethyl etherate, methoxyl group of compound 3 was removed and further converted to 2- 
(cyclopropylamino)-5-methoxybenzenesulfonamide (4) in $63 \%$ yield. 4-Cyclopropyl-7-methoxy-4Hbenzo[e][1,2,4]thiadiazine 1,1-dioxide (5) was formed by a cyclization of compound $\mathbf{4}$ in triethyl orthoformate at $150{ }^{\circ} \mathrm{C}$ in $75 \%$ yield. Reduction of compound $\mathbf{5}$ with $\mathrm{NaBH}_{4}$ in isopropanol provided 4-cyclopropyl-7methoxy-3, 4-dihydro- $2 H$-benzo[ $e][1,2,4]$ thiadiazine 1,1-dioxide (6) in $76 \%$ yield. Desmethylation of compound 6 with boron tribromide in dichloromethane gave 4-cyclopropyl-7-hydroxy-3, 4-dihydro- $2 \mathrm{H}$ benzo[e][1,2,4]thiadiazine 1,1-dioxide (7) in 73\% yield. Compound 7 was reacted with 3methoxybenzeneboronic acid in the presence of copper (II) acetate in dichloromethane through a Chan-Lam coupling reaction ${ }^{27}$ to produce the reference standard compound 8 in $47 \%$ yield. The desmethylated precursor 9 was obtained by desmethylation of compound $\mathbf{8}$ with $\mathrm{BBr}_{3}$ in dichloromethane in $50 \%$ yield. The overall chemical yield for the standard $\mathbf{8}$ and precursor $\mathbf{9}$ in eight and nine steps was $3 \%$ and $1 \%$, respectively. There was no much room to significantly improve the overall yield in reported multiple step synthetic approach. The potential strategy will be redesign of the synthetic route to decrease the reaction steps in the future work.
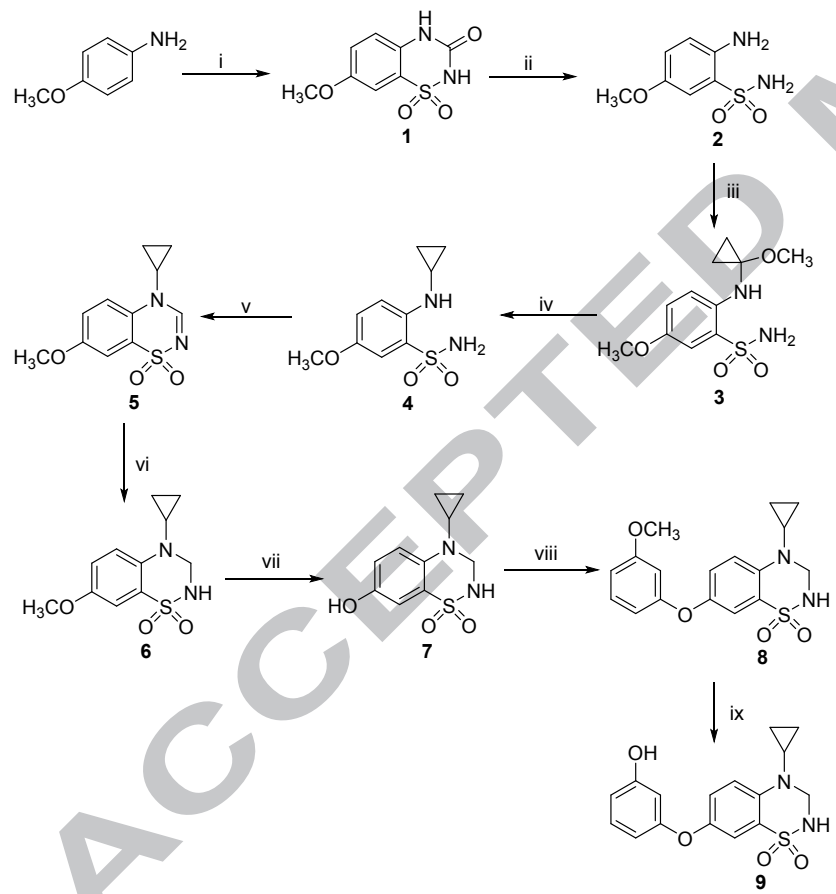

Scheme 1. Synthesis of reference standard (8) and precursor (9). Conditions: (i) (a) $\mathrm{ClSO}_{2} \mathrm{NCO}, 1$-nitro-propane, (b) $\mathrm{AlCl}_{3}, 100{ }^{\circ} \mathrm{C}$; (ii) $\mathrm{H}_{2} \mathrm{SO}_{4}(50 \% \mathrm{wt}), 130{ }^{\circ} \mathrm{C}$; (iii) 1-ethoxycyclopropyloxy trimethylsilane, AcOH, $\mathrm{CH}_{3} \mathrm{OH}$, room temperature (RT); (iv) $\mathrm{NaBH}_{4}$, boron trifluoride diethyl etherate, THF, reflux; (v) triethyl orthoformate, $150{ }^{\circ} \mathrm{C}$; (vi) $\mathrm{NaBH}_{4}$, isopropanol, $50{ }^{\circ} \mathrm{C}$; (vii) $\mathrm{BBr}_{3}, \mathrm{CH}_{2} \mathrm{Cl}_{2}, 0{ }^{\circ} \mathrm{C}$; (viii) 3methoxybenzeneboronic acid, copper (II) acetate, molecular sieves, pyridine, $\mathrm{CH}_{2} \mathrm{Cl}_{2}, 40^{\circ} \mathrm{C}$; (ix) $\mathrm{BBr}_{3}, \mathrm{CH}_{2} \mathrm{Cl}_{2}, 0{ }^{\circ} \mathrm{C}$.

Synthesis of the target tracer $\left[{ }^{11} \mathrm{C}\right] \mathbf{8}$ is presented in Scheme 2. The desmethylated precursor 9 underwent $O$ $\left[{ }^{11} \mathrm{C}\right]$ methylation ${ }^{15}$ using the reactive $\left[{ }^{11} \mathrm{C}\right]$ methylating agent $\left[{ }^{11} \mathrm{C}\right]$ methyl triflate $\left(\left[{ }^{11} \mathrm{C}\right] \mathrm{CH}_{3} \mathrm{OTf}\right)^{28,29}$ in acetonitrile at $80{ }^{\circ} \mathrm{C}$ under basic conditions $(2 \mathrm{~N}$ $\mathrm{NaOH}$ ). The product was isolated by semi-preparative reverse-phase (RP) high performance liquid chromatography (HPLC) with a C-18 column, and then concentrated by solid-phase extraction (SPE) with a disposable C-18 Plus Sep-Pak cartridge to produce the corresponding pure radiolabeled compound $\left[{ }^{11} \mathrm{C}\right] \mathbf{8}$ in $10-15 \%$ radiochemical yield, decay corrected to end of bombardment (EOB), based on $\left[{ }^{11} \mathrm{C}\right] \mathrm{CO}_{2}$.

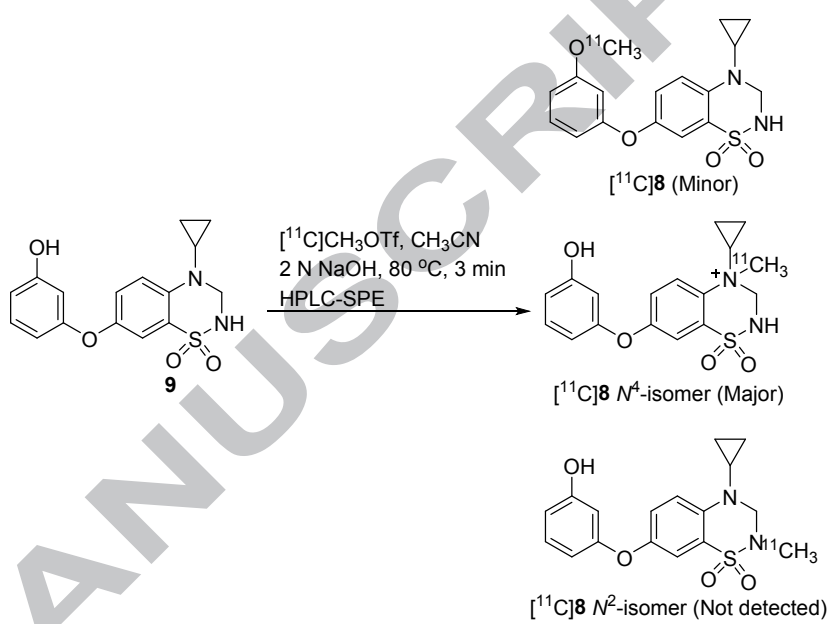

Scheme 2. $\left[{ }^{11} \mathrm{C}\right]$ Methylation reaction of the precursor 9 for the synthesis of target tracer $\left[{ }^{11} \mathrm{C}\right] 8$.

The precursor 9 contains phenol hydroxyl, 4- and 2thiadiazine nitrogen positions that can be $O$ - and $N$ $\left[{ }^{11} \mathrm{C}\right]$ methylated to form $\left[{ }^{11} \mathrm{C}\right] \mathbf{8},\left[{ }^{11} \mathrm{C}\right] \mathbf{8} N^{4}$-isomer, and $\left[{ }^{11} \mathrm{C}\right] \mathbf{8} N^{2}$-isomer, respectively, as indicated in Scheme 2. Based on the $\log \mathrm{P}$ and calculated $\log \mathrm{P}(\mathrm{C} \log \mathrm{P})$ values of $\left[{ }^{11} \mathrm{C}\right] \mathbf{8}$ and its isomers obtained from ChemDraw Professional 18.0 (ChemOffice) as listed in Table 1, we can predict their retention time $\left(t_{R}\right)$ sequence in semi-preparative RP-HPLC system would be $t_{\mathrm{R}}\left[{ }^{11} \mathrm{C}\right] \mathbf{8} N^{2}$-isomer $>\mathrm{t}_{\mathrm{R}}\left[{ }^{11} \mathrm{C}\right] \mathbf{8}>\mathrm{t}_{\mathrm{R}}\left[{ }^{11} \mathrm{C}\right] \mathbf{8} N^{4}$-isomer. Base effect on the radiosynthesis of $\left[{ }^{11} \mathrm{C}\right] \mathbf{8}$ was investigated to maximize the radiochemical yield of desired radiolabeled product. The different bases including solid base sodium hydride $(\mathrm{NaH})$ powder, sodium hydroxide $(\mathrm{NaOH})$, potassium hydroxide $(\mathrm{KOH})$, sodium carbonate $\left(\mathrm{Na}_{2} \mathrm{CO}_{3}\right)$, potassium carbonate $\left(\mathrm{K}_{2} \mathrm{CO}_{3}\right), \mathrm{NaOH}-\mathrm{Na}_{2} \mathrm{CO}_{3}$ (mixed); and liquid base aqueous $\mathrm{NaOH}, \mathrm{KOH}, \mathrm{Na}_{2} \mathrm{CO}_{3}, \mathrm{~K}_{2} \mathrm{CO}_{3}$, sodium bicarbonate $\left(\mathrm{NaHCO}_{3}\right)$ were tested for the radiosynthesis, and $2 \mathrm{~N} \mathrm{NaOH}$ was identified as the best base. The reaction conditions including the reaction solvent, temperature and time were optimized as well. The optimized conditions $\left(\mathrm{CH}_{3} \mathrm{CN}, 2 \mathrm{~N} \mathrm{NaOH}, 80^{\circ} \mathrm{C}, 3\right.$ $\mathrm{min}$ ) are listed and the results are summarized in Scheme 2. $\left[{ }^{11} \mathrm{C}\right] \mathbf{8} N^{2}$-isomer was not detected, $\left[{ }^{11} \mathrm{C}\right] \mathbf{8}$ $N^{4}$-isomer was a major radiolabeled product, and $\left[{ }^{11} \mathrm{C}\right] \mathbf{8}$ was a minor radiolabeled product. These results suggested that 4-thiadiazine nitrogen position of 9 is 
more easily methylated than phenol hydroxyl oxygen position to yield undesired radiolabeled by-product. The radiochemical yield of $\left[{ }^{11} \mathrm{C}\right] \mathbf{8}$ was optimized to $10-15 \%$. The radiochemical yield of $\left[{ }^{11} \mathrm{C}\right] \mathbf{8} N^{4}$-isomer was 45 $50 \%$. Likewise, there was no much room to improve the labeling reaction in one-step radiosynthesis of the desired product $\left[{ }^{11} \mathrm{C}\right] \mathbf{8}$ using non-protected desmethylated precursor due to its chemistry nature. To make the target compound $\left[{ }^{11} \mathrm{C}\right] \mathbf{8}$ as a major product from radiochemistry and synthetic chemistry perspectives, the potential strategy will be redesign of the synthetic route to prepare $N$-protected desmethylated precursor for two-step radiosynthesis of $\left[{ }^{11} \mathrm{C}\right] \mathbf{8}$ in the future work.

The radiosynthesis was performed in a home-built automated multi-purpose $\quad\left[{ }^{11} \mathrm{C}\right]$-radiosynthesis module. ${ }^{30-32}$ Our radiosynthesis module facilitated the overall design of the reaction, purification and reformulation capabilities in a fashion suitable for adaptation to preparation of human doses. The radiosynthesis includes three stages: 1) labeling reaction; 2) purification; and 3) formulation. The overall synthesis time was $35-40$ min from EOB. Our module is also designed to allow in-process measurement of $\left[{ }^{11} \mathrm{C}\right]-$ tracer molar activity $\left(\mathrm{A}_{\mathrm{M}}, \mathrm{GBq} / \mu \mathrm{mol}\right.$ at $\left.\mathrm{EOB}\right)$ using a radiation detector with a UV detector at the outlet of the HPLC-portion of the system. At the end of synthesis (EOS), the $\mathrm{A}_{\mathrm{M}}$ of $\left[{ }^{11} \mathrm{C}\right]$-tracer was determined again by analytical RP-HPLC, calculated, decay corrected to $\mathrm{EOB}$, and based on $\left[{ }^{11} \mathrm{C}\right] \mathrm{CO}_{2}$, which was in agreement with the 'on line' determined value. The $A_{M}$ of $\left[{ }^{11} \mathrm{C}\right] \mathbf{8}$ at EOB was $370-740 \mathrm{GBq} / \mu \mathrm{mol}$.

Chemical purity and radiochemical purity were determined by analytical HPLC. ${ }^{33}$ The chemical purity of the precursor and reference standard was $>93 \%$ determined by RP-HPLC through UV flow detector. The radiochemical purity of the target tracer was $>99 \%$ determined by radio-HPLC through $\gamma$-ray (PIN diode) flow detector.

The octanol-water partition coefficient (commonly expressed as $\log \mathrm{P}$ ) is an important physical parameter directly correlated with the biological activities of a wide variety of organic compounds. ${ }^{34} \log \mathrm{P}$ provides an assessment of lipophilicity that often correlates with a compound's ability to penetrate the blood brain barrier (BBB). Table 1 gives $\log \mathrm{P}$ and $C \log \mathrm{P}$ values of $\left[{ }^{11} \mathrm{C}\right] \mathbf{8}$ and its isomers in comparison with $\left[{ }^{11} \mathrm{C}\right] \mathrm{PIB}$, $\left[{ }^{18} \mathrm{~F}\right]$ Amyvid, $\left[{ }^{11} \mathrm{C}\right] \mathrm{PBB} 3$ and $\left[{ }^{18} \mathrm{~F}\right] \mathrm{T} 807$ (Figure 1), which are obtained from ChemDraw Professional 18.0 (ChemOffice). $\log \mathrm{P}$ data of $\left[{ }^{11} \mathrm{C}\right] \mathbf{8}$ (3.04) is in the range of those of $\left[{ }^{11} \mathrm{C}\right] \mathrm{PIB},\left[{ }^{18} \mathrm{~F}\right]$ Amyvid, $\left[{ }^{11} \mathrm{C}\right] \mathrm{PBB} 3$ and $\left[{ }^{18} \mathrm{~F}\right] \mathrm{T} 807(2.25-4.09)$, which are PET AD imaging agents in clinical evaluation. These data suggest $\left[{ }^{11} \mathrm{C}\right] \mathbf{8}$ has an appropriate lipophilicity for brain uptake.

Table 1. $\log \mathrm{P}$ and $\mathrm{C} \log \mathrm{P}$ values of $\left[{ }^{11} \mathrm{C}\right] \mathbf{8}$ and its isomers in comparison with $\left[{ }^{11} \mathrm{C}\right] \mathrm{PIB},\left[{ }^{18} \mathrm{~F}\right]$ Amyvid, $\left[{ }^{11} \mathrm{C}\right] \mathrm{PBB} 3$ and $\left[{ }^{18} \mathrm{~F}\right] \mathrm{T} 807$ obtained from ChemDraw Professional 18.0 (ChemOffice).

\begin{tabular}{|c|c|c|}
\hline Compound & Log P & CLog P \\
\hline$\left[{ }^{1 \mathbf{C}} \mathbf{C}\right.$ & 3.04 & 3.12 \\
\hline$\left[{ }^{\mathbf{1}} \mathbf{C}\right] \mathbf{8} \boldsymbol{N}^{\mathbf{4}}$-isomer & N/A & 0.023 \\
\hline$\left[{ }^{1 \mathbf{C}} \mathbf{C}\right] \mathbf{8} \boldsymbol{N}^{\mathbf{2}}$-isomer & 3.07 & 3.27 \\
\hline$\left[{ }^{\mathbf{1}} \mathbf{C}\right] \mathbf{P I B}$ & 3.41 & 3.99 \\
\hline$\left[{ }^{\mathbf{1 8}} \mathbf{F}\right] \mathbf{A m y v i d}$ & 3.16 & 3.91 \\
\hline$\left[{ }^{1 \mathbf{C}} \mathbf{C}\right] \mathbf{P B B 3}$ & 4.09 & 4.05 \\
\hline$\left[{ }^{\mathbf{8}} \mathbf{F}\right] \mathbf{T 8 0 7}$ & 2.25 & 3.18 \\
\hline
\end{tabular}

The stability of the labeled tracer $\left[{ }^{11} \mathrm{C}\right] \mathbf{8}$ was evaluated by analytical HPLC from EOS up to $3 \mathrm{~h}$, one injection of the tracer solution in EtOH/saline onto HPLC column per hour. The HPLC chromatograms showed $\left[{ }^{11} \mathrm{C}\right] \mathbf{8}$ was stable without decomposition.

The experimental details and characterization data for compounds 1-9 and for the tracer $\left[{ }^{11} \mathrm{C}\right] \mathbf{8}$ are given. ${ }^{35}$

In summary, facile synthetic routes with moderate to excellent yields have been developed to produce the precursor 9, the reference standard $\mathbf{8}$, and the target PET radiotracer $\left[{ }^{11} \mathrm{C}\right] \mathbf{8}$. The radiosynthesis employed $\left[{ }^{11} \mathrm{C}\right] \mathrm{CH}_{3} \mathrm{OTf}$ for $O-\left[{ }^{11} \mathrm{C}\right]$ methylation at the phenyl hydroxyl position of the precursor, followed by product purification and isolation by a semi-preparative RPHPLC combined with SPE. The base effect on the radiotracer production of $\left[{ }^{11} \mathrm{C}\right] 8$ has been investigated. The desired $\left[{ }^{11} \mathrm{C}\right] \mathbf{8}$ was obtained in reasonable radiochemical yield, and high radiochemical purity, with a reasonably short overall synthesis time, and high molar activity. A new AMPAR radioligand has been successfully radiosynthesized. This will facilitate studies to evaluate the carbon-11-labeled AMPAR allosteric modulator as a new candidate PET radioligand for imaging of $\mathrm{AD}$.

\section{Acknowledgments}

This work was partially supported by the Hebei Province Major Science and Technology Program (No. 17392605D), and the High Level Scientific and Technological Innovation and Entrepreneurial Talent Plan of Shijiazhuang in China. This work was also partially supported by the Indiana University Department of Radiology and Imaging Sciences in the United States.

\section{References and notes}


1. Johnson KA, Fox NC, Sperling RA, Klunk WE. Brain imaging in Alzheimer disease. Cold Spring Harb Perspect Med. 2012;2:a006213.

2. Rathore S, Habes M, Iftikhar MA, Shacklett A, Davatzikos C. A review on neuroimaging-based classification studies and associated feature extraction methods for Alzheimer's disease and its prodromal stages. Neuroimage. 2017;155:530-548.

3. Frisoni GB, Boccardi M, Barkhof F, Blennow K, Cappa S, Chiotis K, Démonet JF, Garibotto V, Giannakopoulos P, Gietl A, Hansson O, Herholz K, Jack CR Jr, Nobili F, Nordberg A, Snyder HM, Ten Kate M, Varrone A, Albanese E, Becker S, Bossuyt P, Carrillo MC, Cerami C, Dubois B, Gallo V, Giacobini E, Gold G, Hurst S, Lönneborg A, Lovblad KO, Mattsson N, Molinuevo JL, Monsch AU, Mosimann U, Padovani A, Picco A, Porteri C, Ratib O, SaintAubert L, Scerri C, Scheltens P, Schott JM, Sonni I, Teipel S, Vineis P, Visser PJ, Yasui Y, Winblad B. Strategic roadmap for an early diagnosis of Alzheimer's disease based on biomarkers. Lancet Neurol. 2017;16:661-676.

4. Okamura N, Harada R, Furukawa K, Furumoto S, Tago T, Yanai K, Arai H, Kudo Y. Advances in the development of tau PET radiotracers and their clinical applications. Ageing Res Rev. 2016;30:107-113.

5. Ota T, Shinotoh H, Fukushi K, Nagatsuka S, Namba H, Iyo M, Aotsuka A, Tanaka N, Sato K, Shiraishi T, Tanada S, Arai H, Irie T. A simple method for the detection of abnormal brain regions in Alzheimer's disease patients using $\left[{ }^{11} \mathrm{C}\right] \mathrm{MP} 4 \mathrm{~A}$ : comparison with [123I]IMP SPECT. Ann Nucl Med. 2004;18:187-193.

6. Sato K, Fukushi K, Shinotoh H, Nagatsuka S, Tanaka N, Aotsuka A, Ota T, Shiraishi T, Tanada S, Iyo M, Irie T. Evaluation of simplified kinetic analyses for measurement of brain acetylcholinesterase activity using $N-\left[{ }^{11} \mathrm{C}\right]$ Methylpiperidin-4-yl propionate and positron emission tomography. J Cereb Blood Flow Metab. 2004;24:600-611.

7. Mochida I, Shimosegawa E, Kanai Y, Naka S, Matsunaga K, Isohashi K, Horitsugi G, Watabe T, Kato H, Hatazawa J. Whole-body distribution of donepezil as an acetylcholinesterase inhibitor after oral administration in normal human subjects: $\mathrm{A}{ }^{11} \mathrm{C}$ donepezil PET Study. Asia Ocean J Nucl Med Biol. 2017;5:3-9.

8. Klunk WE, Engler H, Nordberg A, Bacskai BJ, Wang Y, Price JC, Bergström M, Hyman BT, Långström B, Mathis CA. Imaging the pathology of Alzheimer's disease: amyloid-imaging with positron emission tomography. Neuroimaging Clin N Am. 2003;13:781789.

9. Carpenter AP Jr, Pontecorvo MJ, Hefti FF, Skovronsky DM. The use of the exploratory IND in the evaluation and development of ${ }^{18} \mathrm{~F}$-PET radiopharmaceuticals for amyloid imaging in the brain: a review of one company's experience. Q J Nucl Med Mol Imaging. 2009;53:387-393.
10. Hashimoto H, Kawamura K, Igarashi N, Takei M, Fujishiro T, Aihara Y, Shiomi S, Muto M, Ito T, Furutsuka K, Yamasaki T, Yui J, Xie L, Ono M, Hatori A, Nemoto K, Suhara T, Higuchi M, Zhang MR. Radiosynthesis, photoisomerization, biodistribution, and metabolite analysis of ${ }^{11} \mathrm{C}-\mathrm{PBB} 3$ as a clinically useful PET probe for imaging of tau pathology. J Nucl Med. 2014;55:1532-1538.

11. Chien DT, Bahri S, Szardenings AK, Walsh JC, Mu F, Su MY, Shankle WR, Elizarov A, Kolb HC. Early clinical PET imaging results with the novel PHF-tau radioligand [F-18]-T807. J Alzheimers Dis. 2013;34:457-468.

12. Wang M, Gao M, Miller KD, Sledge GW, Hutchins GD, Zheng Q.-H. The first synthesis of $\left[{ }^{11} \mathrm{C}\right] \mathrm{SB}-$ 216763, a new potential PET agent for imaging of glycogen synthase kinase-3 (GSK-3). Bioorg Med Chem Lett. 2011;21:245-249.

13. Gao M, Wang M, Zheng Q.-H. Synthesis of carbon11-labeled isonicotinamides as new potential PET agents for imaging of GSK-3 enzyme in Alzheimer's disease. Bioorg Med Chem Lett. 2017;27:740-743.

14. Goffin E, Drapier T, Larsen AP, Geubelle P, Ptak CP, Laulumaa S, Rovinskaja K, Gilissen J, Tullio P, Olsen L, Frydenvang K, Pirotte B, Hanson J, Oswald RE, Kastrup JS, Francotte P. 7-Phenoxy-substituted 3,4dihydro-2H-1,2,4-benzothiadiazine 1,1-dioxides as positive allosteric modulators of $\alpha$-amino-3-hydroxy5-methyl-4-isoxazolepropionic acid (AMPA) receptors with nanomolar potency. J Med Chem. 2018;61:251-264.

15. Gao M, Kong D, Clearfield A, Zheng Q.-H. Synthesis of carbon-11 and fluorine-18 labeled $N$-acetyl-1-aryl6,7-dimethoxy-1,2,3,4-tetrahydroisoquinoline derivatives as new potential PET AMPA receptor ligands. Bioorg Med Chem Lett. 2006;16:2229-2233.

16. Arstad E, Gitto R, Chimirri A, Caruso R, Constanti A, Turton D, Hume SP, Ahmad R, Pilowsky LS, Luthra SK. Closing in on the AMPA receptor: synthesis and evaluation of 2-acetyl-1-(4'-chlorophenyl)-6-methoxy7-[ $\left.{ }^{11} \mathrm{C}\right]$ methoxy-1,2,3,4-tetrahydroisoquinoline as a potential PET tracer. Bioorg Med Chem. 2006;14:4712-4717.

17. Oi N, Tokunaga M, Suzuki M, Nagai Y, Nakatani Y, Yamamoto N, Maeda J, Minamimoto T, Zhang MR, Suhara T, Higuchi M. Development of novel PET probes for central 2-amino-3-(3-hydroxy-5-methyl-4isoxazolyl)propionic acid receptors. J Med Chem. 2015;58:8444-8462.

18. Takahata K, Kimura Y, Seki C, Tokunaga M, Ichise M, Kawamura K, Ono M, Kitamura S, Kubota M, Moriguchi S, Ishii T, Takado Y, Niwa F, Endo H, Nagashima T, Ikoma Y, Zhang MR, Suhara T, Higuchi M. A human PET study of $\left[{ }^{11} \mathrm{C}\right] \mathrm{HMS} 011$, a potential radioligand for AMPA receptors. EJNMMI Res. 2017;7:63.

19. Yuan G, Jones GB, Vasdev N, Liang SH. Radiosynthesis and preliminary PET evaluation of ${ }^{18} \mathrm{~F}$ labeled 2-(1-(3-fluorophenyl)-2-oxo-5-(pyrimidin-2- 
yl)-1,2-dihydropyridin-3-yl)benzonitrile for imaging AMPA receptors. Bioorg Med Chem Lett. 2016;26:4857-4860.

20. Chen Z, Mori W, Zhang X, Yamasaki T, Dunn PJ, Zhang G, Fu H, Shao T, Zhang Y, Hatori A, Ma L, Fujinaga M, Xie L, Deng X, Li H, Yu Q, Rong J, Josephson L, Ma JA, Shao Y, Tomita S, Zhang MR, Liang SH. Synthesis, pharmacology and preclinical evaluation of ${ }^{11} \mathrm{C}$-labeled 1,3-dihydro- $2 \mathrm{H}$ benzo[d]imidazole-2-ones for imaging $\gamma 8$-dependent transmembrane AMPA receptor regulatory protein. Eur J Med Chem. 2018;157:898-908.

21. Fu H, Chen Z, Josephson L, Li Z, Liang SH. Positron emission tomography (PET) ligand development for ionotropic glutamate receptors: challenges and opportunities for radiotracer targeting $N$-methyl- ${ }_{-}{ }^{-}$ aspartate (NMDA), $\alpha$-amino-3-hydroxy-5-methyl-4isoxazolepropionic acid (AMPA), and kainate receptors. J Med Chem. 2019;62:403-419.

22. Girard Y, Atkinson JG, Rokach J. A new synthesis of 1,2,4-benzothiadiazines and a selective preparation of o-aminobenzenesulfonamides. J Chem Soc Perkin Trans. 1979;1:1043-1047.

23. Adams JL, Ator LE, Duffy KJ, Graybill TL, Kiesow TJ, Lian Y, Moore ML, Palph JM, Ridgers LH. Benzothiadiazine compounds. WO 2017098421A1.

24. Alexander A, Shalimov TI, Chudakova YG, Vlasenko $\mathrm{AD}$, Sinitsa PP. Heterocyclization of $\mathrm{N}$ (chlorosulfonyl)imidoyl chlorides with anilines, a new method of synthesis of 1,2,4-benzothiadiazine 1,1dioxides. Chem Heterocycl Comp. 2016;52:267-274.

25. Varano F, Catarzi D, Colotta V, Squarcialupi L, Matucci R. 1,2,4-Benzothiadiazine-1,1-dioxide derivatives as ionotropic glutamate receptor ligands: synthesis and structure-activity relationships. Arch Pharm Chem Life Sci. 2014;347:777-785.

26. Krintel C, Francotte P, Pickering DS, Juknaite L, Pøhlsgaard J, Olsen L, Frydenvang K, Goffin E, Pirotte B, Kastrup JS. Enthalpy-entropy compensation in the binding of modulators at ionotropic glutamate receptor GluA2. Biophys J. 2016;110:2397-2406.

27. Lam PYS, Vincent G, Clark CG, Deudon S, Jadhav PK. Copper-catalyzed general $\mathrm{C}-\mathrm{N}$ and $\mathrm{C}-\mathrm{O}$ bond cross-coupling with arylboronic acid. Tetrahedron Lett. 2001;42:3415-3418.

28. Jewett DM. A simple synthesis of $\left[{ }^{11} \mathrm{C}\right]$ methyl triflate. Int J Rad Appl Instrum A. 1992;43:1383-1385.

29. Mock BH, Mulholland GK, Vavrek MT. Convenient gas phase bromination of $\left[{ }^{11} \mathrm{C}\right]$ methane and production of $\left[{ }^{11} \mathrm{C}\right]$ methyl triflate. Nucl Med Biol. 1999;26:467471.

30. Wang M, Gao M, Zheng Q.-H. Fully automated synthesis of PET TSPO radioligands $\left[{ }^{11} \mathrm{C}\right] \mathrm{DAA} 1106$ and $\left[{ }^{18}\right.$ F]FEDAA1106. Appl Radiat Isot. 2012;70:965973.

31. Mock BH, Zheng Q.-H, DeGrado TR. A multipurpose ${ }^{11} \mathrm{C}$-radio-synthesis system. J Labelled Compd Radiopharm. 2005;48:S225.
32. Mock BH, Glick-Wilson BE, Zheng Q.-H, DeGrado TR. Automated measurement of specific activity of radiolabeled ligands during synthesis. J Labelled Compd Radiopharm. 2005;48:S224.

33. Zheng Q.-H, Mock BH. Purification of carbon-11 PET radiotracers from unlabeled precursors by preparative HPLC and SPE. Biomed Chromatogr. 2005;19:671676.

34. Wang X, Dong F, Miao C, Li W, Wang M, Gao M, Zheng Q.-H, Xu Z. Synthesis of carbon-11-labeled 5$\mathrm{HT}_{6} \mathrm{R}$ antagonists as new candidate PET radioligands for imaging of Alzheimer's disease. Bioorg Med Chem Lett. 2018;28:1836-1841.

35. (a). General: All commercial reagents and solvents were purchased from Sigma-Aldrich and Fisher Scientific, and used without further purification. $\left[{ }^{11} \mathrm{C}_{\mathrm{CH}_{3}} \mathrm{OTf}\right.$ was prepared according to a literature procedure. ${ }^{29}$ Melting points were determined on WRR apparatus and were uncorrected. ${ }^{1} \mathrm{H}$ and ${ }^{13} \mathrm{C}$ NMR spectra were recorded on a Bruker Avance II 400 or $600 \mathrm{MHz}$ NMR Fourier transform spectrometer at 400, 600 or $100 \mathrm{MHz}$, respectively. Chemical shifts $(\delta)$ are reported in parts per million (ppm) relative to an internal standard tetramethylsilane (TMS, $\delta$ 0.0) ( ${ }^{1} \mathrm{H}$ NMR) and to the solvent signal $\left({ }^{13} \mathrm{C}\right.$ NMR), and coupling constants $(J)$ are reported in hertz $(\mathrm{Hz})$. Liquid chromatography-mass spectra (LC-MS) analysis was performed on AB Sciex 4000Q Trap instrument, consisting of an 1100 series HPLC connected to a diode array detector and a 1946D mass spectrometer configured for positive-ion/negative-ion electrospray ionization (ESI). The high resolution mass spectra (HRMS) were obtained using a Waters/Micromass LCT Classic spectrometer. Chromatographic solvent proportions are indicated as volume : volume ratio. Thin-layer chromatography (TLC) was run using HS silica gel GF254 uniplates (5 $\times 10 \mathrm{~cm}^{2}$ ). Plates were visualized under UV light. Normal phase flash column chromatography was carried out on Combiflash Rf 150 silica gel 60 (300400 mesh) with a forced flow of the indicated solvent system in the proportions described below. All moisture- and air-sensitive reactions were performed under a positive pressure of nitrogen maintained by a direct line from a nitrogen source. Analytical RP HPLC was performed using a Prodigy (Phenomenex) $5 \mu \mathrm{m}$ C-18 column, $4.6 \times 250 \mathrm{~mm}$, mobile phase $65 \%$ $\mathrm{CH}_{3} \mathrm{CN} / 35 \% \quad 4.0 \mathrm{mM} \mathrm{CH} \mathrm{CH}_{3} \mathrm{COONa}$, flow rate 1.0 $\mathrm{mL} / \mathrm{min}$; UV (254 nm) and $\gamma$-ray (PIN diode) flow detectors. Semi-preparative RP HPLC column was performed using a Prodigy (Phenomenex) $5 \mu \mathrm{m} \mathrm{C}-18$ column, $10 \times 250 \mathrm{~mm} ; 70 \% \mathrm{CH}_{3} \mathrm{CN}: 30 \% \mathrm{H}_{2} \mathrm{O}$ mobile phase; $6 \mathrm{~mL} / \mathrm{min}$ flow rate; UV $(254 \mathrm{~nm})$ and $\gamma$-ray (PIN diode) flow detectors. C18 Plus Sep-Pak cartridges were obtained from Waters Corporation (Milford, MA). Sterile Millex-FG $0.2 \mu \mathrm{m}$ filter units were obtained from Millipore Corporation (Bedford, MA). 
(b). 7-Methoxy-2H-benzo[e][1,2,4]thiadiazin-3(4H)one 1,1-dioxide (1): To a stirred solution of chlorosulfonyl isocyanate $(1.79 \mathrm{~g}, 12.30 \mathrm{mmol})$ in 1 nitropropane $(10 \mathrm{~mL})$, 4-methoxyaniline $(1.23 \mathrm{~g}, 10.0$ $\mathrm{mmol})$ in 1-nitropropane $(20.0 \mathrm{~mL})$ was added at $0{ }^{\circ} \mathrm{C}$ during $5 \mathrm{~min}$. The purple chlorosulfonylurea intermediate was formed after the reaction mixture was stirred at $0{ }^{\circ} \mathrm{C}$ for $30 \mathrm{~min}$. Then, the anhydrous aluminum chloride $\left(\mathrm{AlCl}_{3}\right)(1.68 \mathrm{~g}, 12.7 \mathrm{mmol})$ was added quickly, a clear solution was formed. The reaction mixture was heated, and stirred at $100{ }^{\circ} \mathrm{C}$ for $1 \mathrm{~h}$, then cooled to room temperature (RT), and poured into stirred ice water. The precipitation was filtered, washed with water, and purified by recrystallization in ethanol to afford 1 as a pale yellow solid $(1.87 \mathrm{~g}$, $82 \%$ ), mp 298.7-301.2 ${ }^{\circ} \mathrm{C}$. ${ }^{1} \mathrm{H}$ NMR (400 MHz, DMSO-d6): $\delta 9.22(\mathrm{~s}, 1 \mathrm{H}), 6.89(\mathrm{t}, J=2.4 \mathrm{~Hz}, 1 \mathrm{H})$, $6.95(\mathrm{~d}, J=2.4 \mathrm{~Hz}, 1 \mathrm{H}), 6.92(\mathrm{~d}, J=8.8 \mathrm{~Hz}, 1 \mathrm{H}), 3.75$ (s, 3H). LC-MS (ESI, $\mathrm{m} / \mathrm{z}$ ): Calcd for $\mathrm{C}_{8} \mathrm{H}_{9} \mathrm{~N}_{2} \mathrm{O}_{4} \mathrm{~S}$ $\left([\mathrm{M}+\mathrm{H}]^{+}\right)$229.03, found: 229.03 .

(c). 2-Amino-5-methoxybenzenesulfonamide (2): Compound $1(0.51 \mathrm{~g}, 2.2 \mathrm{mmol})$ was added to a stirred solution of $\mathrm{H}_{2} \mathrm{SO}_{4}(15 \mathrm{~mL}, 50 \% \mathrm{wt})$ at $\mathrm{RT}$, the resulting reaction mixture was heated to $130-140{ }^{\circ} \mathrm{C}$, and the reaction was continued for $3 \mathrm{~h}$. The reaction mixture was cooled to $25^{\circ} \mathrm{C}$, and then poured into ice water $(100 \mathrm{~mL})$. The solution was neutralized with $\mathrm{NaOH}(40 \%)$, and extracted with EtOAc $(3 \times 60 \mathrm{~mL})$. The combined organic layer was washed with water, brine, dried over anhydrous $\mathrm{Na}_{2} \mathrm{SO}_{4}$ and filtered. The solvent was evaporated under vacuum. The crude product was purified by silica gel column chromatography with EtOAc/petroleum ether (PE) (1:10 to $1: 4)$ as eluent to afford 2 as a pale yellow solid (0.21 g, 46\%), mp 118.3-119.7 ${ }^{\circ} \mathrm{C} .{ }^{1} \mathrm{H}$ NMR (600 MHz, DMSO-d6): $\delta 7.23(\mathrm{~s}, 2 \mathrm{H}), 7.11(\mathrm{~d}, J=3.0 \mathrm{~Hz}$, $1 \mathrm{H}), 6.93(\mathrm{dd}, J=9.0,3.0 \mathrm{~Hz}, 1 \mathrm{H}), 6.77(\mathrm{~d}, J=9.0$ $\mathrm{Hz}, 1 \mathrm{H}), 5.43$ (s, 2H), 3.67 (s, 3H). LC-MS (ESI, $m / z)$ : Calcd for $\mathrm{C}_{7} \mathrm{H}_{11} \mathrm{~N}_{2} \mathrm{O}_{3} \mathrm{~S}\left([\mathrm{M}+\mathrm{H}]^{+}\right)$203.05, found: 203.01.

(d).

5-Methoxy-2-((1-

methoxycyclopropyl)amino)benzenesulfonamide (3): To a stirred solution of $2(1.00 \mathrm{~g} ; 4.9 \mathrm{mmol})$ in methanol $(20 \mathrm{~mL}), \quad$ (1-ethoxycyclopropyloxy) trimethylsilane $(4 \mathrm{~mL})$ and glacial acetic acid $(4 \mathrm{~mL})$ were added at RT. After refluxed for $18 \mathrm{~h}$, the reaction mixture was evaporated to dry under reduced pressure. The resulted oily residue was treated with water (30 $\mathrm{mL})$, and extracted with $\mathrm{CHCl}_{3}(3 \times 30 \mathrm{~mL})$. The combined organic layer was washed with water, brine, dried over anhydrous $\mathrm{Na}_{2} \mathrm{SO}_{4}$ and filtered. The solvent was removed under vacuum. The crude product was purified by silica gel column chromatography with EtOAc/PE (1:20 to 1:5) as eluent to afford 3 as a white solid $(0.80 \mathrm{~g}, 61 \%), \mathrm{mp} 147.5-149.4{ }^{\circ} \mathrm{C} .{ }^{1} \mathrm{H}$ NMR $(600$ $\left.\mathrm{MHz}, \mathrm{CDCl}_{3}\right): \delta 7.41(\mathrm{~d}, J=9.0 \mathrm{~Hz}, 1 \mathrm{H}), 7.34(\mathrm{~d}, J=$ $3.0 \mathrm{~Hz}, 1 \mathrm{H}), 7.07$ (dd, $J=9.0,3.0 \mathrm{~Hz}, 1 \mathrm{H}), 6.48(\mathrm{~s}$, $1 \mathrm{H}), 4.86(\mathrm{~s}, 2 \mathrm{H}), 3.78(\mathrm{~s}, 3 \mathrm{H}), 3.28(\mathrm{~s}, 3 \mathrm{H}), 1.15(\mathrm{t}, J$ $=5.4 \mathrm{~Hz}, 2 \mathrm{H}), 0.90(\mathrm{t}, J=4.8 \mathrm{~Hz}, 2 \mathrm{H}) . \mathrm{LC}-\mathrm{MS}(\mathrm{ESI}$, $m / z$ ): Calcd for $\mathrm{C}_{11} \mathrm{H}_{17} \mathrm{~N}_{2} \mathrm{O}_{4} \mathrm{~S}\left([\mathrm{M}+\mathrm{H}]^{+}\right) 273.09$, found: 273.10 .

(e).

2-(Cyclopropylamino)-5methoxybenzenesulfonamide (4): To a stirred solution of $3(0.80 \mathrm{~g}, 2.94 \mathrm{mmol})$ in THF $(50 \mathrm{~mL}), \mathrm{NaBH}_{4}$ $(2.00 \mathrm{~g}, 52.9 \mathrm{mmol})$, and boron trifluoride diethyl etherate $(2 \mathrm{~mL})$ were added at RT. The reaction mixture was then refluxed for $16 \mathrm{~h}$. The solvent was evaporated under vacuum. The resulted oily residue was treated with water $(30 \mathrm{~mL})$ and the $\mathrm{pH}$ was adjusted to 4 with aqueous $6 \mathrm{~N} \mathrm{HCl}$ solution. The mixture was extracted with $\mathrm{CHCl}_{3}(3 \times 30 \mathrm{~mL})$, and the combined organic layer was washed with water, brine, dried over anhydrous $\mathrm{Na}_{2} \mathrm{SO}_{4}$ and filtered. The organic mixture was evaporated under vacuum, and the crude product was purified by silica gel column chromatography with EtOAc/PE (1:10 to $1: 4)$ as eluent to afford 4 as a white solid $(0.46 \mathrm{~g}, 63 \%), \mathrm{mp}$ 116.5-118.7 ${ }^{\circ} \mathrm{C} .{ }^{1} \mathrm{H}$ NMR $\left(600 \mathrm{MHz}, \mathrm{CDCl}_{3}\right): \delta 7.35$ $(\mathrm{d}, J=3.0 \mathrm{~Hz}, 1 \mathrm{H}), 7.23(\mathrm{~d}, J=9.0 \mathrm{~Hz}, 1 \mathrm{H}), 7.07(\mathrm{dd}$, $J=9.0,3.0 \mathrm{~Hz}, 1 \mathrm{H}), 5.65(\mathrm{~s}, 1 \mathrm{H}), 4.84(\mathrm{~s}, 2 \mathrm{H}), 3.78$ (s, 3H), $2.47-2.45(\mathrm{~m}, 1 \mathrm{H}), 0.81-0.78(\mathrm{~m}, 2 \mathrm{H}), 0.53$ - 0.51 (m, 2H). LC-MS (ESI, $\mathrm{m} / \mathrm{z}$ ): Calcd for $\mathrm{C}_{10} \mathrm{H}_{15} \mathrm{~N}_{2} \mathrm{O}_{3} \mathrm{~S}\left([\mathrm{M}+\mathrm{H}]^{+}\right)$243.08, found: 243.20 .

(f). 4-Cyclopropyl-7-methoxy-4Hbenzo[e][1,2,4]thiadiazine 1,1-dioxide (5): A stirred solution of $4(0.45 \mathrm{~g}, 1.86 \mathrm{mmol})$ in triethyl orthoformate $(10 \mathrm{~mL})$ was heated to $150{ }^{\circ} \mathrm{C}$, and the reaction mixture was refluxed for $6 \mathrm{~h}$. After cooled on an ice-bath, the solid product was collected by filtration, and washed with diethyl ether. The product was purified by recrystallization in methanol to afford 5 as a white solid $(0.35 \mathrm{~g}, 75 \%), \mathrm{mp} 229.8-230.2{ }^{\circ} \mathrm{C}$. ${ }^{1} \mathrm{H}$ NMR (600 MHz, DMSO-d6): $\delta 8.07(\mathrm{~s}, 1 \mathrm{H}), 7.80$ $(\mathrm{d}, J=9.0 \mathrm{~Hz}, 1 \mathrm{H}), 7.41(\mathrm{dd}, J=9.6,3.0 \mathrm{~Hz}, 1 \mathrm{H})$, $7.31(\mathrm{~d}, J=3.0 \mathrm{~Hz}, 1 \mathrm{H}), 3.87(\mathrm{~s}, 3 \mathrm{H}), 3.39-3.36(\mathrm{~m}$, 1H), $1.17-1.14(\mathrm{~m}, 2 \mathrm{H}), 1.10-0.98(\mathrm{~m}, 2 \mathrm{H})$. LC-MS (ESI, $m / z)$ : Calcd for $\mathrm{C}_{11} \mathrm{H}_{13} \mathrm{~N}_{2} \mathrm{O}_{3} \mathrm{~S}\left([\mathrm{M}+\mathrm{H}]^{+}\right)$253.06, found: 253.07 .

(g). 4-Cyclopropyl-7-methoxy-3, 4-dihydro-2Hbenzo[e][1,2,4]thiadiazine 1,1-dioxide (6): To a stirred solution of $5(0.28 \mathrm{~g}, 1.11 \mathrm{mmol})$ in isopropyl alcohol $(7 \mathrm{~mL}), \mathrm{NaBH}_{4}(0.14 \mathrm{~g}, 3.71 \mathrm{mmol})$ was added at RT, and the reaction mixture was heated to $50{ }^{\circ} \mathrm{C}$ for $10 \mathrm{~min}$. The reaction mixture was evaporated to dry under vacuum. The resulted oily residue was treated with water $(10 \mathrm{~mL})$ and the $\mathrm{pH}$ was adjusted to 4 with aqueous $6 \mathrm{~N} \mathrm{HCl}$ solution. The resulted solution was extracted with $\mathrm{CH}_{2} \mathrm{Cl}_{2}(3 \times 20$ $\mathrm{mL}$ ). The combined organic layer was washed with water, brine, dried over anhydrous $\mathrm{Na}_{2} \mathrm{SO}_{4}$ and filtered. The organic mixture was evaporated under vacuum. The resulted crude product was purified by silica gel column chromatography with EtOAc/PE (1:10 to $1: 4)$ as eluent to afford $\mathbf{6}$ as a white solid (0.21 g, 76\%), mp 160.8-161.2 ${ }^{\circ} \mathrm{C} .{ }^{1} \mathrm{H}$ NMR (600 $\left.\mathrm{MHz}, \mathrm{CDCl}_{3}\right): \delta 7.27(\mathrm{~s}, 1 \mathrm{H}), 7.15(\mathrm{~d}, J=3.0 \mathrm{~Hz}, 1 \mathrm{H})$, $7.02(\mathrm{dd}, J=9.6,3.0 \mathrm{~Hz}, 1 \mathrm{H}), 4.82(\mathrm{t}, J=8.4 \mathrm{~Hz}, 1 \mathrm{H})$, $4.69(\mathrm{~d}, J=8.4 \mathrm{~Hz}, 2 \mathrm{H}), 3.78(\mathrm{~s}, 3 \mathrm{H}), 2.36-2.35(\mathrm{~m}$, 
1H), $0.94-0.91(\mathrm{~m}, 2 \mathrm{H}), 0.70-0.68(\mathrm{~m}, 2 \mathrm{H})$. LC-MS (ESI, $m / z)$ : Calcd for $\mathrm{C}_{11} \mathrm{H}_{15} \mathrm{~N}_{2} \mathrm{O}_{3} \mathrm{~S}\left([\mathrm{M}+\mathrm{H}]^{+}\right)$255.08, found: 255.08 .

(h). 4-Cyclopropyl-7-hydroxy-3,4-dihydro-2Hbenzo[e][1,2,4]thiadiazine 1,1-dioxide (7): To a stirred solution of $6(0.2 \mathrm{~g}, 0.79 \mathrm{mmol})$ in $\mathrm{CH}_{2} \mathrm{Cl}_{2}(12$ $\mathrm{mL}), \mathrm{BBr}_{3}(0.3 \mathrm{~mL})$ was added slowly at $0{ }^{\circ} \mathrm{C}$, and the reaction continued at $0{ }^{\circ} \mathrm{C}$ for $20 \mathrm{~h}$. The reaction mixture was poured into ice water $(10 \mathrm{~mL})$, and then the dichloromethane was removed under reduced pressure. The resulted aqueous solution was extracted with EtOAc $(3 \times 40 \mathrm{~mL})$, and the combined organic layer was washed with water, brine, dried over anhydrous $\mathrm{Na}_{2} \mathrm{SO}_{4}$ and filtered. The organic solution was evaporated under vacuum, and the resulted crude product was purified by silica gel column chromatography with EtOAc/PE (1:10 to $1: 2)$ as eluent to afford 7 as a white solid $(0.14 \mathrm{~g}, 73 \%), \mathrm{mp}$ 175.5-177.9 ${ }^{\circ} \mathrm{C} .{ }^{1} \mathrm{H}$ NMR (600 MHz, DMSO-d6): $\delta$ $9.32(\mathrm{~s}, 1 \mathrm{H}), 7.82(\mathrm{t}, J=7.8 \mathrm{~Hz}, 1 \mathrm{H}), 0.19(\mathrm{~d}, J=9.0$ $\mathrm{Hz}, 1 \mathrm{H}), 6.94(\mathrm{dd}, J=9.0,3.0 \mathrm{~Hz}, 1 \mathrm{H}), 6.92(\mathrm{~d}, J=$ $3.0 \mathrm{~Hz}, 1 \mathrm{H}), 4.55(\mathrm{~d}, J=7.8 \mathrm{~Hz}, 2 \mathrm{H}), 2.39-2.36(\mathrm{~m}$, 1H), $0.86-0.83(\mathrm{~m}, 2 \mathrm{H}), 0.62-0.60(\mathrm{~m}, 2 \mathrm{H})$. LC-MS (ESI, $m / z)$ : Calcd for $\mathrm{C}_{10} \mathrm{H}_{13} \mathrm{~N}_{2} \mathrm{O}_{3} \mathrm{~S}\left([\mathrm{M}+\mathrm{H}]^{+}\right)$241.06, found: 241.06 .

(i). 4-Cyclopropyl-7-(3-methoxyphenoxy)-3,4-dihydro2H-benzo[e][1,2,4]thiadiazine 1,1-dioxide (8): To a stirred solution of $7(0.32 \mathrm{~g}, 1.3 \mathrm{mmol})$ in $\mathrm{CH}_{2} \mathrm{Cl}_{2}(40$ $\mathrm{mL}$ ), pyridine (8 drops), molecular sieves $(4 \mathrm{~g}), 3$ methoxybenzeneboronic acid $(0.30 \mathrm{~g}, 2.0 \mathrm{mmol})$, and copper (II) acetate $(0.63 \mathrm{~g}, 2.0 \mathrm{mmol})$ were added at RT. The reaction mixture was stirred at $40{ }^{\circ} \mathrm{C}$ for $5 \mathrm{~h}$, and then $\mathrm{CH}_{2} \mathrm{Cl}_{2}(15 \mathrm{~mL})$ was added to the reaction mixture. The solid was removed from the reaction mixture by filtration, and the resulted organic solution was evaporated under vacuum. The resulted residue was suspended with aqueous $\mathrm{HCl}(\mathrm{pH}=5-6)$ solution $(50 \mathrm{~mL})$, and then the resulted aqueous solution was extracted with EtOAc $(3 \times 50 \mathrm{~mL})$. The combined organic layer was washed with water, brine, dried over anhydrous $\mathrm{Na}_{2} \mathrm{SO}_{4}$ and filtered. The solvent was evaporated under vacuum. The crude product was purified by silica gel column chromatography with EtOAc/PE (1:10 to 1:5) as eluent to afford 8 as a white solid (0.22 g, 47\%), mp 151.2-152.7 ${ }^{\circ} \mathrm{C} .{ }^{1} \mathrm{H}$ NMR (600 $\left.\mathrm{MHz}, \mathrm{CDCl}_{3}\right): \delta 7.26(\mathrm{~d}, J=2.4 \mathrm{~Hz}, 1 \mathrm{H}), 7.32(\mathrm{~d}, J=$ $9.0 \mathrm{~Hz}, 1 \mathrm{H}), 7.21(\mathrm{t}, J=8.4 \mathrm{~Hz}, 1 \mathrm{H}), 7.14(\mathrm{dd}, J=9.0$, $2.4 \mathrm{~Hz}, 1 \mathrm{H}), 6.65-6.64(\mathrm{~m}, 1 \mathrm{H}), 6.54-6.52(\mathrm{~m}, 2 \mathrm{H})$, $4.76-4.70(\mathrm{~m}, 3 \mathrm{H}), 3.78(\mathrm{~s}, 3 \mathrm{H}), 2.42-2.38(\mathrm{~m}, 1 \mathrm{H})$, $0.98-0.95(\mathrm{~m}, 2 \mathrm{H}), 0.73-0.70(\mathrm{~m}, 2 \mathrm{H})$. LC-MS (ESI, $m / z)$ : Calcd for $\mathrm{C}_{17} \mathrm{H}_{19} \mathrm{~N}_{2} \mathrm{O}_{4} \mathrm{~S}\left([\mathrm{M}+\mathrm{H}]^{+}\right) 347.11$, found: 347.10 .

(j). 4-Cyclopropyl-7-(3-hydroxyphenoxy)-3,4-dihydro2 -benzo[e][1,2,4]thiadiazine 1,1-dioxide (9): Compound 9 was prepared by referring to the synthesis procedure of compound 7 as a white solid $(0.13 \mathrm{~g}, 50 \%)$, mp 166.4-168.4 ${ }^{\circ} \mathrm{C} .{ }^{1} \mathrm{H}$ NMR (400 $\left.\mathrm{MHz}, \mathrm{CD}_{3} \mathrm{OD}\right): \delta 7.43(\mathrm{~d}, J=9.2 \mathrm{~Hz}, 1 \mathrm{H}), 7.23-7.14$ $(\mathrm{m}, 3 \mathrm{H}), 6.56(\mathrm{dd}, J=8.4,2.4 \mathrm{~Hz}, 1 \mathrm{H}), 6.45-6.41$ (m,
2H), $4.75(\mathrm{~s}, 2 \mathrm{H}), 2.52-2.45(\mathrm{~m}, 1 \mathrm{H}), 1.01-0.97(\mathrm{~m}$, 2H), $0.79-0.76(\mathrm{~m}, 2 \mathrm{H}) .{ }^{13} \mathrm{C}$ NMR $(100 \mathrm{MHz}$, $\left.\mathrm{CD}_{3} \mathrm{OD}\right): \delta 158.88,158.84,148.23,140.98,129.94$, $124.83,123.77,116.48,114.54,110.05,108.44$, 104.90, 61.31, 29.48, 7.86 (overlap, 2C). HRMS (ESI, $m / z)$ : Calcd for $\mathrm{C}_{16} \mathrm{H}_{17} \mathrm{~N}_{2} \mathrm{O}_{4} \mathrm{~S}\left([\mathrm{M}+\mathrm{H}]^{+}\right)$333.0904, found: 333.0904 .

(k). 4-Cyclopropyl-7-(3-[ $\left[{ }^{11} C\right]$ methoxyphenoxy)-3,4dihydro-2H-benzo[e][1,2,4]thiadiazine 1,1-dioxide $\left(\left[{ }^{11} \mathrm{C}\right] 8\right)$ : $\left[{ }^{11} \mathrm{C}\right] \mathrm{CO}_{2}$ was produced by the ${ }^{14} \mathrm{~N}(\mathrm{p}, \alpha){ }^{11} \mathrm{C}$ nuclear reaction in the small volume $\left(9.5 \mathrm{~cm}^{3}\right)$ aluminum gas target provided with the Siemens RDS111 Eclipse cyclotron. The target gas consisted of 1\% oxygen in nitrogen purchased as a specialty gas from Praxair, Indianapolis, IN. Typical irradiations used for the development were $58 \mu \mathrm{A}$ beam current and $20 \mathrm{~min}$ on target. The production run produced approximately $37.0 \mathrm{GBq}$ of $\left[{ }^{11} \mathrm{C}\right] \mathrm{CO}_{2}$ at EOB. The precursor $9(0.1-$ $0.3 \mathrm{mg})$ was dissolved in $\mathrm{CH}_{3} \mathrm{CN}(500 \mu \mathrm{L})$. To this solution was added aqueous $\mathrm{NaOH}(2 \mathrm{~N}, 2 \mu \mathrm{L})$. The mixture was transferred to a small reaction vial. Nocarrier-added (high molar activity) $\left[{ }^{11} \mathrm{C}\right] \mathrm{CH}_{3} \mathrm{OTf}$ that was produced by the gas-phase production method ${ }^{29}$ within $12 \mathrm{~min}$ from $\left[{ }^{11} \mathrm{C}\right] \mathrm{CO}_{2}$ through $\left[{ }^{11} \mathrm{C}^{-} \mathrm{CH}_{4}\right.$ and $\left[{ }^{11} \mathrm{C} \mathrm{CH}_{3} \mathrm{Br}\right.$ with $\mathrm{AgOTf}$ column was passed into the reaction vial at RT until radioactivity reached a maximum $(2 \mathrm{~min})$, and then the reaction vial was isolated and heated at $80^{\circ} \mathrm{C}$ for $3 \mathrm{~min}$. The contents of the reaction vial were diluted with aqueous $\mathrm{NaHCO}_{3}$ $(0.1 \mathrm{M}, 1 \mathrm{~mL})$. The reaction vial was connected to a 3mL HPLC injection loop. The labeled product mixture solution was injected onto the semi-preparative HPLC column for purification. The product fraction was collected in a recovery vial containing $30 \mathrm{~mL}$ water. The diluted tracer solution was then passed through a C-18 Plus Sep-Pak cartridge, and washed with water $(3 \times 10 \mathrm{~mL})$. The cartridge was eluted with $\mathrm{EtOH}(3 \times$ $0.4 \mathrm{~mL}$ ) to release the labeled product, followed by saline $(10-11 \mathrm{~mL})$. The eluted product was then sterile-filtered through a Millex-FG $0.2 \mu \mathrm{m}$ membrane into a sterile vial. Total radioactivity was assayed and total volume $(10-11 \mathrm{~mL})$ was noted for tracer dose dispensing. The overall synthesis time including HPLC-SPE purification and reformulation was 35-40 min from EOB. The decay corrected radiochemical yield was $10-15 \%$. Retention times in the analytical RP-HPLC system were: $t_{R} \mathbf{9}=4.55 \mathrm{~min}, \mathrm{t}_{\mathrm{R}} \mathbf{8}=7.02$ min, and $t_{R}\left[{ }^{11} \mathrm{C}\right] \mathbf{8}=7.10 \mathrm{~min}$. Retention times in the preparative RP-HPLC system were: $t_{R} 9=4.87 \mathrm{~min}, t_{R}$ $\mathbf{8}=8.10 \mathrm{~min}$, and $\mathrm{t}_{\mathrm{R}}\left[{ }^{11} \mathrm{C}\right] \mathbf{8}=8.21 \mathrm{~min}$. 
Radiosynthesis of a carbon-11-labeled AMPAR allosteric modulator as a new PET radioligand candidate for imaging of Alzheimer's disease

Caihong Miao, Fugui Dong, Limeng Jia, Wei Li, Min Wang, Qi-Huang Zheng, Zhidong Xu<smiles></smiles>

Carbon-11-labeled AMPAR allosteric modulator 